\title{
The effect of disinfection of alginate impressions with $35 \%$ beetle juice spray on stone model linear dimensional changes
}

\author{
Anggra Yudha Ramadianto, Zulia Hasratiningsih, Rosida Manurung \\ Department of Dental Material Science \& Technology Faculty of Dentistry Universitas Padjadjaran
}

\begin{abstract}
Dimensional stability of alginate impression is very important for treatment in dentistry. This study was to find the effect of the beetle juice spray procedure on alginate impression on gypsum model linear dimensional changes. This experimental study used 25 samples, divided into 5 groups. The first group, as control, were the alginate impressions filled with dental stone immediately after forming. The other four groups were the alginate impressions gel spray each 1,2,3, and 4 times with $35 \%$ beetle juice and then filled with dental stone. Dimensional changes were measured in the lower part of the plaster model from buccal-lingual and mesial-distal direction and also measured in the outer distance between the upper part of the stone model by using Mitutoyo digital micrometer and profile projector scaled $0,001 \mathrm{~mm}$. The results of mesial-distal diameter average of control group and group 2,3,4, and 5 were $9.909 \mathrm{~mm}, 9.852 \mathrm{~mm}, 9.845 \mathrm{~mm}, 9.824 \mathrm{~mm}$, and $9.754 \mathrm{~mm}$. Meanwhile, the results of buccal-lingual diameter average were $9.847 \mathrm{~mm}, 9.841 \mathrm{~mm}, 9.826 \mathrm{~mm}, 9.776 \mathrm{~mm}$, and $9.729 \mathrm{~mm}$. The results of the outer distance between the upper part of the stone model were $31.739 \mathrm{~mm}, 31.689 \mathrm{~mm}, 31.682 \mathrm{~mm}$, $31.670 \mathrm{~mm}$, and $31.670 \mathrm{~mm}$. The data of this study was evaluated statistically based on variant analysis. The conclusion of this study was statistically, there was no significant effect on gypsum model linear dimensional changes obtained from alginate impressions sprayed with $35 \%$ beetle juice.
\end{abstract}

Key words: Alginate impression, beetle juice spray, stone model, linear dimensional

\section{INTRODUCTION}

Impression material in dentistry has its function to acquire a negative tooth impression and its surrounding tissues which then the positive reproduction is made by pouring the impression with stone models or other filling materials and let it set. One of the impression materials used extensively in dentistry is alginate. Alginate impression material has many advantages, such as good elasticity, easy to manipulate, low cost, comfortable for the patients, simple to use, as well as accurate enough when manipulated well. ${ }^{1-3}$

Other than those advantages, alginate impression has its own shortages, such as easily undergoes dimensional changes after being removed from the mouth due to air contact leading to shrinking as a result from evaporation, or syneresis, and when soaked in the water it will swell due to water absorption, referred as imbibition. Stone model yielded by alginate impression undergoing imbibition will not be accurate because of the reduced impression vault. Hence, the impression pouring should 
be done immediately after the impression has been removed from inside the mouth to prevent dimensional changes. ${ }^{2,4}$

The dentist's area of work includes oral cavity that is full with various germs and bacteria, so there is a great probability for contamination. Cross contamination can occur through alginate impression as a medium for germ transfer from patients to dentists as well as to laboratory technicians. The prevention of this cross contamination can be carried out by disinfection of alginate impression. ${ }^{2,3}$

One of possible disinfection methods for impression materials is by soaking or spraying the alginate impression material using certain disinfectants. The action of disinfection using spray is preferable for impression materials with a tendency to distort when disinfected by soaking like alginate and polyether. Moreover, the model yielded will be optimum when alginate disinfection technique using spray is applied. ${ }^{2,5,6}$

Indonesia has traditional materials that can function as disinfectants. One of the materials is betel leaf that is frequently used to heal nosebleed, red-eyed, menstruation, toothache, as well as to generate clear voice. One of the compounds of betel leaf which has the antiseptic characteristic is cavicol. Cavicol is five times more effective for antiseptic substance than common phenols. ${ }^{7-10}$ Based on a study by Satari et al. ${ }^{11}$ it is shown that betel juice with a concentration of $35 \%$ is capable of inhibiting bacteria growth.

According to the result above, the author aimed at conducting a study regarding alginate impression disinfection using the spray technique with $35 \%$ betel juice as the disinfectant. The observation on the results of treatment on the alginate impression was in the form of dimensional changes of dental stone produced from alginate impression cast.

\section{METHODS AND MATERIALS}

This study is a pure experimental research applied on stone model obtained from alginate impression treated with $35 \%$ betel juice spray, each for 1,2,4, and 4 times and alginate impression rinsed by running water as control.

Specimen preparation was carried out in Dental Material Technology Laboratory, Faculty of Dentistry, Universitas Padjadjaran whereas measurement of sample was conducted at the Laboratory of Industrial Metrology, Machine Engineering Department, Bandung Institute of Technology. The preparation and the measurement of specimens were carried out in September 2006.

\section{Specimen preparations}

The number of specimens used in the study was 25 , divided into five groups, each comprised of five samples: Group I. Control group composed of five alginate impressions rinsed by running water, and then poured with dental stone type III; Group II. Treatment group comprised of five alginate impressions sprayed once with $35 \%$ betel juice, wrapped with a moist towel with disinfectant substance, kept in a closed plastic bag for 10 minutes, and then poured with dental stone type III; Group III. Treatment group comprised of five alginate impressions with the same treatment as group II with twice spraying, and then poured with dental stone type III; Group IV. Treatment group comprised of five alginate impressions with the same treatment as group II with three times spraying, and then poured with dental stone type III; Group V. Treatment group comprised of five alginate impressions with the same treatment as group II with four times spraying, and then poured with dental stone type III.

Instruments used in the study were as follow: digital micrometer; digital analytical balance; master model; alginate spatula; stone spatula; impression tray; measure glass, time measurement instrument; vibrator; spray bottle; plastic bag, plastic box; and towel. Materials used in the study were as follow: alginate from kromopan; dental stone type iii from moldano; $35 \%$ betel juice; and tap water.

\section{Procedure}

Steps carried out in the study were as follow: Master model preparation: master model material was made of stainless steel imitating two prepared fixed denture abutment teeth; Each fixed denture abutment tooth has a vertical slope angle of $6^{\circ}$ in up conical direction; The outer distance between two fixed denture abutment teeth was $30.00 \mathrm{~mm}$, the lower part diameter was $10.00 \mathrm{~mm}$, and the height of each was $11.00 \mathrm{~mm}$. 
Material preparation before a series of research steps were as follow: Alginate powder was put into a plastic container and stirred for one minute until homogenous before using; Dental stone powder type III was put into a plastic container and stirred for one minute before using; Water used in preparing the impression and soaking was measured with a measure glass.

\section{Preparing $35 \%$ betel juice}

Steps for preparing $35 \%$ betel juice were as follow: 35 gram of betel leaves were washed and strained, and then minced thinly; Betel leaves were boiled in $100 \mathrm{ml}$ of water for 15 minutes; of the boiled betel leaves were cooled and filtered into a container using a sterile lint; Sterile water was added to the final volume of $100 \mathrm{ml}$; Betel juice was cooled and poured into a closed plastic bottle.

\section{Sample preparation}

Steps in preparing the sample were as follow: (1) Alginate powder that has been analytically balanced according to W/P ratio was poured into a rubber bowl filled with water; (2) Alginate powder that has been mixed with water was mixed using a spatula with a pressure on the side of the bowl. This process was done with a strong and quick motion, forming a number of 8 , in order to leave out air bubble. Time of mixing was 1 minute; (3) Alginate mixture with refined consistency was poured into a specific tray; (4) Master model was impressed with alginate mixture; (5) Alginate impression was left for three minutes until it sets; (6) Tray was removed from the master model with a quick motion to prevent any distortion on the alginate impression ${ }^{3}$; (7) The impression was washed by running water and left for one minute in order to put the alginate impression back to its original position after undergoing shape alteration when the metal model was removed from the impression; (8) For group I, alginate impression was washed by running water, and shook until there was no water left on it, and then poured with dental stone; (9) For group II, alginate impression was washed by running water and shook until there was no water left on it. Afterwards, 35\% betel juice was sprayed once on the impression with the spray position perpendicular to the impression, and then wrapped with a moist towel with disinfectant substance and stored in a closed plastic bag for 10 minutes. Thereupon, the impression was taken out from the bag, and the towel was taken off. The impression was then rinsed by running water until it is clean and then poured with dental stone; (10) For group III, alginate impression was treated twice with the same treatment as of group II, and then poured with dental stone; (11) For group IV, alginate impression was treated three times with the same treatment as of group II, and then poured with dental stone. For group $\mathrm{V}$, alginate impression was treated four times with the same treatment as of group II, and then poured with dental stone.

\section{Gypsum pouring}

The procedure of gypsum pouring in the study was as follow: Stone powder was analytically balanced. Dental stone type III mixture was made with a comparison of water and power of $0: 3$; The powder was poured into a rubber bowl filled with water until the entire powder was drenched; The mixture was mixed and the bowl was put onto a vibrator. The frequency was two cycles per second for one minute until there was no air bubble left; Stone mixture was put into each of alginate impression; The stone model was removed from the alginate impression after 60 minutes.

\section{Stone model measurement}

The obtained stone model was left for 24 hours before linear dimensional measurement is conducted. Linear dimension was a measure acquired from a measurement of one straight line based on two standard points; The diameter of the lower part (base) of each left and right abutment teeth was measured using a digital micrometer and the results were recorded; The results were summed up and averaged; The outer distance between both upper parts of left and right abutment was measured using a digital micrometer and the results were recorded; The results were summed up and averaged; The average value of each group was compared.

\section{RESULTS}

The objective of this study was to observe the effect of disinfection of alginate impression by spray on gypsum model linear dimensional change. Analysis used was a comparative one, 


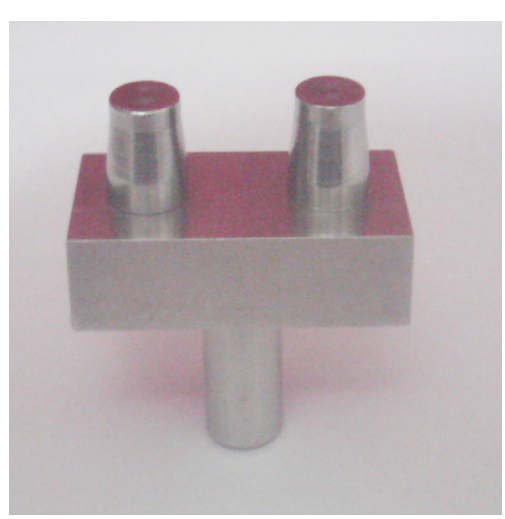

Figure 1. Master model research.

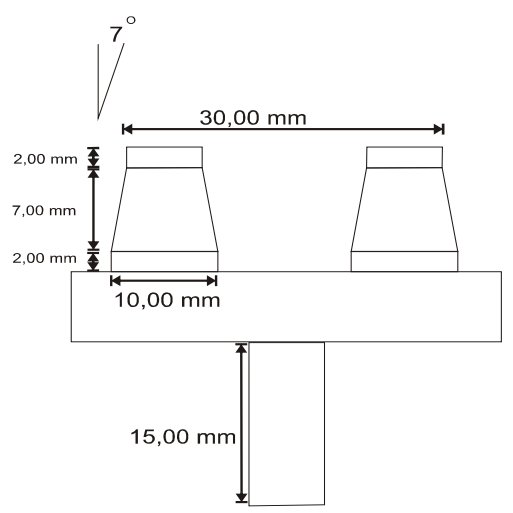

Figure 2. Master model research schematically.

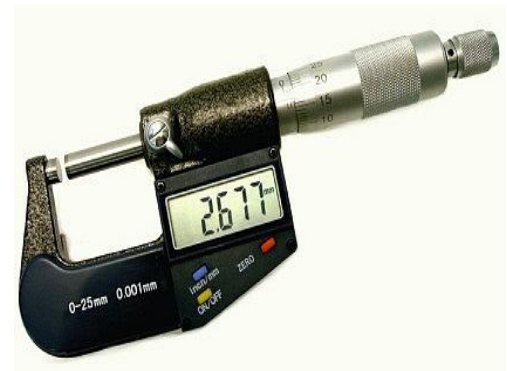

Figure 3. Digital micromotor.

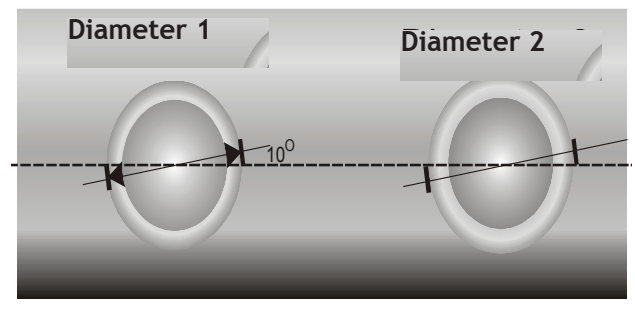

Figure 4. Model measurement from mesial-distal direction.

using analysis of variance for complete randomize design. Comparison of treatment effects comprised of control and $35 \%$ of betel juice spray each for one, two, three, and four times.

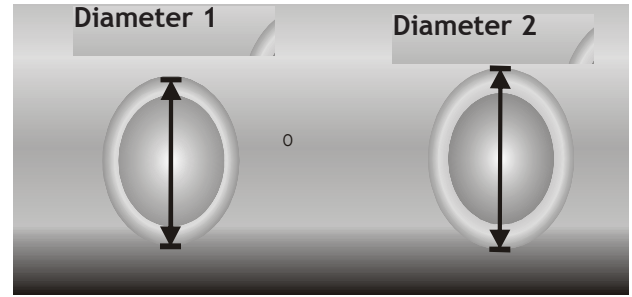

Figure 5. Model measurement from buccal-lingual direction.

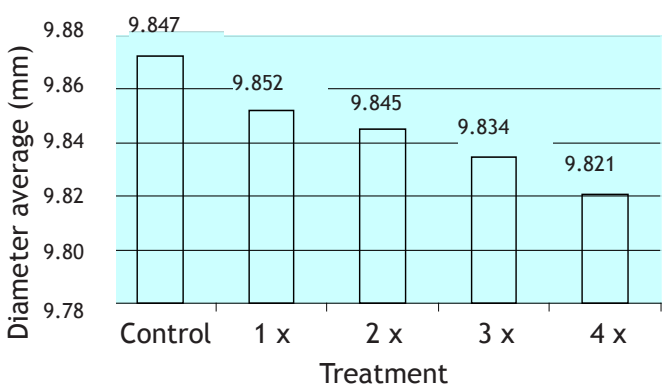

Figure 6. Comparison of buccal-lingual diameter of plaster model as effect of difference treatment

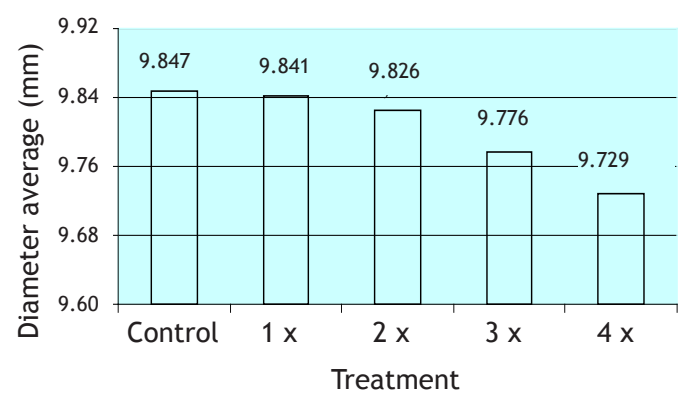

Figure 7. Comparison of mesial-distal diameter of plaster model as effect of difference treatment

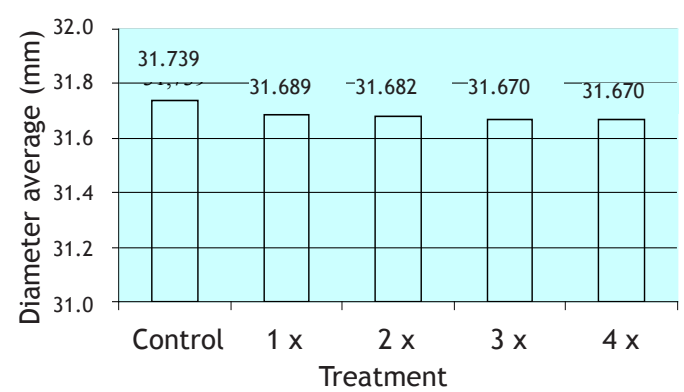

Figure 8. Comparison of averaged outer distance of two upper parts diameter of left and right prop tooth of stone model.

Measurement was done on stone model. Parts measured were the lower part diameter of stone model from buccal-lingual and mesial-distal direction and also the outer distance between both upper parts diameter of left and right prop tooth. 
Table 1. Analysis varians of the effect of desinfection alginate impressions with spray method to bukal-lingual diameter of plaster model.

\begin{tabular}{lcccccc}
\hline \multicolumn{1}{c}{ Variation source } & $\mathrm{dk}$ & $\mathrm{JK}$ & $\mathrm{KT}$ & $\mathrm{F}_{\text {count }}$ & $\mathrm{F}_{\text {table }}$ & Criteria \\
\hline Average & 1 & $2.423,081$ & & & & \\
Treatment & 4 & 0.0075 & 0.0019 & 2.730 & 2.866 & Ho accepted \\
Error & 20 & 0.0138 & 0.0007 & & & \\
\hline \multicolumn{1}{c}{ Total } & 25 & $\mathbf{2 . 4 2 3 , 1 0 2}$ & & & & \\
\hline
\end{tabular}

Table 3. Analysis varians of the effect of desinfection alginate impressions with spray method to mesial-distal diameter of plaster model

\begin{tabular}{lcccccc}
\hline \multicolumn{1}{c}{ Variation source } & $\mathrm{Dk}$ & $\mathrm{JK}$ & $\mathrm{KT}$ & $\mathrm{F}_{\text {count }}$ & $\mathrm{F}_{\text {table }}$ & Criteria \\
\hline Average & 1 & $2.402,764$ & & & & \\
Treatment & 4 & 0.0508 & 0.0127 & 1.999 & 2.866 & Ho accepted \\
Error & 20 & 0.1272 & 0.0064 & & & \\
\hline \multicolumn{1}{c}{ Total } & 25 & $2.402,942$ & & & & \\
\hline
\end{tabular}

Table 4. Analysis varians of the effect of desinfection alginate impressions with spray method to distance of plaster model

\begin{tabular}{lcccccc}
\hline Variation source & $\mathrm{dk}$ & $\mathrm{JK}$ & $\mathrm{KT}$ & $\mathrm{F}_{\text {count }}$ & $\mathrm{F}_{\text {table }}$ & Criteria \\
\hline Average & 1 & $25.106,212$ & & & & \\
Treatment & 4 & 0.0166 & 0.0042 & 0.598 & 2.866 & Ho accepted \\
Error & 20 & 0.1389 & 0.0069 & & & \\
\hline \multicolumn{1}{c}{ Total } & 25 & $25.106,368$ & & & & \\
\hline
\end{tabular}

Note:*: Signifikan at $\alpha=0,05$

The effect of disinfection of alginate impression bysprayongypsummodel buccal-lingual diameter

The comparison of averaged gypsum model buccal-lingual diameter between control group and the other four groups treated with $35 \%$ of betel juice spray for one, two, three, and four times was shown in the following diagram:

To ensure the significance of the averaged buccal-lingual diameter differences, a test through analysis of variance was done for complete randomize design as follows:

Based on analysis of variance above, it can be concluded that there was no significant effects on gypsum model between control group and the four groups treated with $35 \%$ of betel juice spray each for one, two, three, and four times concerning the buccal-lingual diameter of stone model.

The effect of disinfection of alginate impression by spray on gypsum model mesial-distal diameter

The comparison of averaged gypsum model mesial-distal diameter between control group and the other four groups treated with $35 \%$ of betel juice spray for one, two, three, and four times was shown in the following diagram:

To ensure the significance of the averaged mesial-distal diameter differences, a test through analysis of variance was done for complete randomize design as follows:

Based on analysis of variance above, it can be concluded that there was no significant effects on gypsum model between control group and the four groups treated with $35 \%$ of betel juice spray each for one, two, three, and four times concerning the mesial-distal diameter of stone model.

The effect of disinfection of alginate impression by spray on the outer distance between both upper parts diameter of left and right prop tooth of stone model

The comparison of averaged outer distance between both upper parts diameter of left and right prop tooth between control group and groups treated with $35 \%$ of betel juice spray each for one, 
two, three, four times was shown in the following diagram:

To ensure the significance of the averaged distance differences, a test through analysis of variance was done for complete randomize design as follows:

Based on analysis of variance above, it can be concluded that there was no significant effects of disinfection of alginate impression with different spray technique on the outer distance between both upper parts diameter of left and right prop tooth of stone model.

\section{DISCUSSION}

Based on statistically calculation, gypsum dimensional changes occurred insignificantly. However, the reduction on gypsum model linear dimensional measure was in accordance with the amount of disinfectant sprayed in form of $35 \%$ of betel juice. This disinfectant substance contains a significant amount of water as the solvent. Anusavice $^{4}$ explained that liquid absorption by alginate impression will cause the impression to swell, or also called as imbibition. This characteristic that caused the alginate impression to absorb water contained in the $35 \%$ of juice betel. Water absorption by alginate impression results in the swelling of the impression and effects on both diameter reduction and outer distance of the two upper parts diameter of left and right prop tooth on the impression vault. The reduction of the impression vault is followed by the dimensional change on stone model.

Statistically insignificant dimensional changes on stone model between control group and groups treated with $35 \%$ of betel juice spray each for one, two, three, and four times was resulted from the method in applying the disinfection of alginate impression with a condition where there was less disinfectant substance contacted with the impression. Although statistically the linear dimensional change was insignificant, when viewed clinically from the field of dentistry, the average of measurement results will effect on gypsum model accuracy necessarily for cast metal restoration.

\section{CONCLUSION AND SUGGESTION}

Based on the results of the study, it can be concluded as follow: Spray on alginate impressions using $35 \%$ of betel juice didn't effect significantly on gypsum model linear dimensional changes obtained. Disinfection of alginate impressions by spraying of disinfectant material, especially $35 \%$ of betel juice can be applied in the field of dentistry; Disinfection of alginate impressions is advisable carried out by considering time recommended by manufacturers; Further studies regarding alginate impression dimensional change disinfected with betel juice spray are needed using more ideal models and measure tools; Further studies regarding disinfection of alginate impression with betel juice spray viewed microbiologically are needed.

\section{REFERENCES}

1. ADA. Guide to dental materials and devices. $7^{\text {th }}$ ed. USA: American Dental Association; 1974-5. p. 89-91.

2. Anusavice JK. Phillips's science of dental materials. $5^{\text {th }}$ ed. USA: Saunders; 1994. p. 6573,246 .

3. Anusavice JK. Phillips's science of dental materials. $8^{\text {th }}$ ed. USA: Saunders; 2003. p. 239,246.

4. Craig RG, O Brien WJ, Powers JM. Dental materials properties and manipulation. $6^{\text {th }}$ ed. St. Louis: The C.V. Mosby Co.; 1996. p. 145-55.

5. Craig RG, Peyton FA. Restorative dental materiasls. $8^{\text {th }}$ ed. USA: Mosby Inc.; 1971. p. 187, 190.

6. Powers JM. Restorative dental materials. St. Louis: The C.V. Mosby Co.; 2002. p. 330-9.

7. Craig RG, Powers JM. Dental materials properties and manipulation. $7^{\text {th }}$ ed. St. Louis: The C.V. Mosby Co.; 2000. p. 202.

8. Darwis SN. Potensi sirih (Piper betle l.) Sebagai tanaman obat. Warta Tumbuhan Obat Indonesia 1992;1(1):9-11.

9. Departemen Kesehatan Republik Indonesia. 1980. Farmakope Indonesia. Edisi III. Jakarta: Departemen Kesehatan RI; 1980. 
10. Djulaeha E. Khasiat obat kumur infusa daun kacapirirng terhadap perubahan mikroorganisme rongga mulut pemakai gigi tiruan lepasan. MI Kedokteran Gigi FKG USAKTI 1999.

11. Gladwin M, Bagby M. Clinical aspects of dental materials. USA: Lippincott Williams \& Wilkins; 2000. p. 100-1,109,280-2.

12. Glick M. Dental management of patient with HIV. Hong Kong: Quintessence Publishing Co, Inc.; 1994. p. 257.

13. Guenther E. The essential oils, Vol II. In: Prayogo BEW, Sutaryadi. Pemanfaatan sirih untuk pelayanan kesehatan primer. Warta Tumbuhan Obat Indonesia 1949.

14. Hatrick CD, Eakle WS, Bird WF. Clinical applications for dental assistants and dental hygienist. USA: Saunders; 2003. p. 202-17.

15. Hegnauer $R$, Pflanzen $C D$, Verlag $B$, Stutgart $B$. In: Prayogo BEW, Sutaryadi. Pemanfaatan sirih untuk pelayanan kesehatan primer. Warta Tumbuhan Obat Indonesia 1969.

16. Hernani SY. Peranan sirih sebagai obat tradisional. Warta Tumbuhan Obat Indonesia 1992:1(1):13.

17. Mc Cabe JF, Walls AWG. Applied dental materials. $7^{\text {th }}$ ed. Cambridge: The University Press.; 1990. p. 121.

18. Miller $\mathrm{CH}$, Palenik CJ. Infection control and management of hazardous materials for the dental team. USA: Mosby Inc.; 1994. p. 8097.

19. Newman MG, Nisengard RJ. Oral microbiology and immunology. $2^{\text {nd }}$ ed. Philadelpia: W.B.
Saunders Co.; 1994. p. 403,409-13.

20. Noort VR. Introduction to dental materials. USA: Mosby Inc.; 1994. p. 162-5.

21. Phillips RW, Swartz ML, Norman RD. Materials for the practicing dentist. St. Louis: The C.V. Mosby Co.; 1969. p. 110,115-6.

22. Phillips RW. Science on dental materials. $7^{\text {th }}$ ed. Philadelphia: W.B. Saunders Co.; 1973. p. 115-8.

23. Science on dental materials. $9^{\text {th }}$ ed. Philadelphia: W.B. Saunders Co.; 1996. p. 110.

24. Phillips RW, Moore BK. Elements of dental materials for dental hygienist and dental assistants. $5^{\text {th }}$ ed. Philadelphia: W.B. Saunders Co.; 1994. p. 65-73.

25. Prayogo BE, Sutaryadi W. Pemanfaatan sirih untuk pelayanan kesehatan primer. Warta Tumbuhan Indonesia 1992;1(1):9.

26. Satari HM, Mulyana Y, Usman R. Usaha Pemeriksaan daya antimikroba dari ekstrak daun sirih (Piper betle l) terhadap beberapa bakteri. Buku Kumpulan Makalah IImiah Kongres Nasional XVI Persatuan Dokter Gigi Indonesia 1985. p. 266-9.

27. Triarsari D. Daun sirih mengobati mimisan sampai keputihan. Situs internet Departemen Kesehatan Indonesia. 2006. [cited 2006 Sept]. Available from:http://www.depkes.go.id.

28. Wikipedia Indonesia. Sirih. Situs internet Wikipedia Indonesia. 2005. [cited 2006 Sept]. Available from:http: //www.google.co.id.

29. Willet NP, White RR, Rosen S. Essential dental microbiology. Prentice-Hall Int. Inc.; 1991. p. 55-8. 